\title{
ANALISIS TINGKAT KESEHATAN BANK PADA PT BANK MUAMALAT INDONESIA, TbK DENGAN MENGGUNAKAN METODE RGEC (RISK PROFILE, GOOD CORPORATE GOVERNANCE, EARNING \& CAPITAL) PERIODE 2013 - 2017
}

\author{
${ }^{1)}$ Zeze Zakaria Hamzah, ${ }^{2)}$ Dewi Anggraini \\ ${ }^{1)}$ Dosen Program Studi Manajemen, STIE Dewantara \\ Jl. Raya Pemda Bojong Depok Baru III, Karadenan, Cibinong, Bogor, Jawa Barat 16913,Indonesia \\ Email: zeze.zakaria@dewantara.ac.id \\ ${ }^{2)}$ Alumni Program Studi Manajemen, STIE Dewantara \\ Jl. Raya Pemda Bojong Depok Baru III, Karadenan, Cibinong, Bogor, Jawa Barat 16913, Indonesia \\ Email: dewianggr25@gmail.com
}

\begin{abstract}
This study aims to determine the health level of Bank Muamalat in 2013-2017 in terms of aspects of Risk Profile, Good Corporate Governance, Earning \& Capital. The data analysis technique used is the analysis of the soundness of the bank. The results of the study showed that during 2013-2017: (1) the Aspects of Risk Profile in NPF in 2013 were in the very healthy predicate, in 2014-2015 in the predicate of being quite healthy, in 2016-2017 in the predicate of health. FDR in 2013, 2014, 2015, 2016 and 2017 respectively in the title is quite healthy, healthy, quite healthy, quite healthy and healthy. (2) GCG aspects during 2013-2017 ranked 1 in very good condition, ranked 3 quite well, ranked 3 quite well, ranked 2 good and ranked 3 quite well. (3) Earning aspects of the 2013 ROA indicator are healthy, 2014-2017 are in a less healthy condition. ROE in 2013 was in a fairly healthy condition, 2014-2017 was in an unhealthy condition and BOPO in 2013 was quite healthy, 2014-2017 was in an unhealthy condition (4) Capital aspect with CAR value in 2013-2017 was in a very bad condition healthy. (5) The overall aspect of RGEC is in a less healthy condition with a composite rating of 4 .
\end{abstract}

Keywords: Bank Soundness, Risk Profile, GCG, Rentability, Capital.

\section{ABSTRAK}

Penelitian ini bertujuan untuk mengetahui tingkat kesehatan Bank Muamalat tahun 2013-2017 ditinjau dari aspek Risk Profile, Good Corporate Governance, Earning \& Capital. Teknik analisis data yang digunakan adalah analisis tingkat kesehatan bank. Hasil penelitian menunjukkan bahwa selama tahun 2013-2017: (1) Aspek Risk Profile pada NPF tahun 2013 dalam predikat sangat sehat, tahun 20142015 dalam predikat cukup sehat, tahun 2016-2017 dalam predikat sehat. FDR pada tahun 2013, 2014, 2015, 2016 dan 2017 berturut-turut dalam predikat cukup sehat, sehat, cukup sehat, cukup sehat dan sehat. (2) Aspek GCG selama tahun 2013-2017 mendapat peringkat 1 dalam kondisi sangat baik, peringkat 3 cukup baik, peringkat 3 cukup baik, peringkat 2 baik dan peringkat 3 cukup baik. (3) Aspek Earning pada indikator ROA tahun 2013 dalam kondisi sehat, tahun 2014-2017 dalam kondisi kurang sehat. ROE pada tahun 2013 dalam kondisi cukup sehat, tahun 2014-2017 dalam kondisi kurang sehat dan BOPO pada tahun 2013 dalam kondisi cukup sehat, tahun 2014-2017 dalam kondisi tidak sehat (4) Aspek Capital dengan nilai CAR tahun 2013-2017 dalam kondisi sangat sehat. (5) Aspek RGEC secara keseluruhan dalam kondisi kurang sehat dengan peringkat komposit 4.

Kata kunci : Kesehatan Bank, Profil Risiko, GCG, Rentabilitas, Permodalan.

\section{PENDAHULUAN}

Semakin berkembangnya pertumbuhan bank saat ini, memicu pertanyaan apakah bank tersebut dalam keadaan sehat atau tidak. Berdasarkan data Statistik Perbankan Syariah, hingga akhir tahun 2017, total aset perbankan syariah baru mencapai $\mathrm{Rp} 424,181$ triliun atau 5,97 persen dari total aset perbankan.
Berdasarkan data per Juni 2016, dari total 12 bank umum syariah, terdapat lima bank yang terjerat tingginya rasio NPF gross. Lima bank itu adalah Bank Maybank Syariah Indonesia sebesar 29,31 persen, Bank Jawa Barat Banten Syariah 17,09 persen, Bank Victoria Syariah 12,03 persen, Bank Muamalat Indonesia 7,23 persen dan Bank Syariah Mandiri 5,58 persen. 
Rasio NPF gross masing-masing lima bank tersebut di atas rata-rata rasio NPF gross perbankan umum syariah dan unit usaha syariah secara industri yaitu sebesar 5,68 persen pada Juni dan 5,32 persen pada Juli lalu. Kelima bank tersebut tetap membukukan NPF tinggi meski NPF industri sudah berangsur membaik dari level 6,17 persen pada bulan Mei tahun 2016. (sumber: katadata.co.id). Perkembangan metodologi penilaian kondisi bank senantiasa bersifat dinamis sehingga sistem penilaian tingkat kesehatan bank perlu di review secara periodik untuk menyesuaikan kondisi terkini. Untuk mengetahui kondisi tersebut, diperlukan suatu analisis tingkat kesehatan bank yang diatur pada Peraturan Bank Indonesia (PBI) Nomor 13/1/PBI/2011 tanggal 5 Januari 2011 tentang Penilaian Tingkat Kesehatan Bank Umum. PBI tersebut menggantikan PBI sebelumnya No. 6/10/PBI/2004 tentang Sistem Penilaian Tingkat Kesehatan Bank Umum yang telah berlaku selama hampir tujuh tahun.

\subsection{Rumusan Masalah}

Untuk itu rumusan masalah dalam penelitian ini adalah:

1. Bagaimana tingkat kesehatan bank pada laporan keuangan di PT Bank Muamalat Indonesia, Tbk pada periode 2013-2017?

2. Bagaimana profil risiko (risk profile); good corporate governance (GCG); rentabilitas (earnings) dan permodalan (capital) selama lima tahun pada PT Bank Muamalat Indonesia, Tbk?

\subsection{Tujuan Penelitian}

1. Untuk mengetahui tingkat kesehatan bank pada laporan keuangan di PT Bank Muamalat Indonesia, Tbk pada periode $2013-2017$

2. Untuk mengetahui profil risiko (risk profile); good corporate governance (GCG); rentabilitas (earnings) dan permodalan (capital) selama lima tahun pada PT Bank Muamalat Indonesia, Tbk

\section{TINJAUAN PUSTAKA}

\subsection{Kesehatan Bank}

Tingkat kesehatan bank Menurut Ikatan Bankir Indonesia (2016:10) merupakan hasil penilaian atas berbagai aspek yang berpengaruh terhadap kondisi atau kinerja suatu bank. Penilaian terhadap faktor-faktor tersebut dilakukan melalui penilaian secara kuantitatif dan/atau kualitatif setelah mempertimbangkan unsur judgement yang didasarkan atas materialitas dari faktor-faktor penilaian, serta pengaruh dari faktor lain seperti kondisi industri perbankan dan perekonomian.

Pokok-pokok pengaturan tingkat kesehatan bank per Januari 2012 seluruh Bank Umum di Indonesia sudah harus menggunakan pedoman penilaian tingkat kesehatan bank yang terbaru berdasarkan Peraturan Bank Indonesia (PBI) No.13/1/PBI/2011 tentang Penilaian Tingkat Kesehatan Bank Umum. Tata cara terbaru tersebut, disebut sebagai Metode RGEC yaitu singkatan dari Risk Profile, Good Corporate Governance, Earning, dan Capital.

Zeze (2018) menyatkaan bahwa tingkat kesehatan perusahaan diperlukan untuk mengetahui kondisi keuangan perusahaan tersebut baik atau tidak. Hal ini dapat dilakukan dengan membandingkan antara rasio tahun sebelumnya dengan rasio pada saat ini.

Pedoman perhitungan selengkapnya diatur dalam Surat Edaran (SE) Bank Indonesia No.13/24/DPNP tanggal 25 Oktober 2011 tentang Penilaian Tingkat Kesehatan Bank Umum tersebut merupakan petunjuk pelaksanaan dari Peraturan Bank Indonesia No.13/1/PBI/2011, yang mewajibkan Bank Umum untuk melakukan penilaian sendiri (self assessment). Tingkat Kesehatan Bank dengan menggunakan pendekatan Risiko (Risk-based Bank Rating/RBBR) baik secara individual maupun secara konsolidasi.

\subsection{Pendekatan Risiko (Risk Based Bank Rating/RBBR)}

Risk-Based Bank Rating (RBBR) adalah penilaian tingkat kesehatan bank dengan 
menggunakan PBI No. 13/01/PBI/2011 tentang penilaian Tingkat Kesehatan Bank Umum, serta sebagaimana diatur dalam SE Bank Indonesia No. 13/24/DPNP/2011 tanggal 25 Oktober 2011 tentang Penilaian Tingkat Kesehatan Bank Umum, yang mewajibkan bank umum untuk melakukan penilaian sendiri (self assessment) tingkat kesehatan bank dengan menggunakan pendekatan risiko (RiskBased Bank Rating/RBBR), baik secara individual maupun secara konsolidasi. Self assessment RBBR dilakukan paling kurang setiap semester untuk posisi akhir bulan Juni dan Desember.

Hasil self assessment tersebut disampaikan ke BI:

a. Untuk RBBR secara individual, paling lambat pada tanggal 31 Juli untuk posisi akhir bulan Juni dan 31 Januari untuk posisi akhir bulan Desember; dan

b. Untuk RBBR secara konsolidasi, paling lambat pada tanggal 15 Agustus untuk posisi akhir bulan Juni dan 15 Februari untuk posisi akhir bulan Desember.

Tujuan Risk-Based Bank Rating/ RBBR antara lain:

1. Untuk mewujudkan visi Arsitektur Perbankan Indonesia (API) yaitu mencapai suatu sistem perbankan yang sehat, kuat dan efisien guna mendorong pertumbuhan ekonomi nasional.

2. Memperoleh gambaran mengenai tingkat kesehatan bank dan seluruh aspeknya, sehingga dapat digunakan sebagai input bank dalam:

a. Menyusun strategi dan rencana bisnis ke depan.

b. Memperbaiki kelemahan- kelemahan yang berpotensi menganggu kinerja bank.

c. Bagi regulator, penilaian tingkat kesehatan bank menjadi input dalam menyusun strategi dan rencana pengawasan bank yang efektif.

Tingkat Kesehatan Bank merupakan hasil penilaian dari kondisi bank yang dilakukan terhadap risiko dan kinerja bank untuk menjalankan fungsinya dengan baik.

Tabel 1. Peringkat Komposit Kesehatan Bank

\begin{tabular}{cc}
\hline Peringkat & Penjelasan \\
\hline PK 1 & Sangat Sehat \\
\hline PK 2 & Sehat \\
\hline PK 3 & Cukup Sehat \\
\hline PK 4 & Kurang Sehat \\
\hline PK 5 & Tidak Sehat \\
\hline $\begin{array}{l}\text { Sumber : Peraturan } \\
\text { 13/01/PBI/2011 }\end{array}$ & Bank Indonesia No.
\end{tabular}

Sesuai Peraturan Bank Indonesia No. 13/01/PBI/2011 tentang penilaian Tingkat Kesehatan Bank Umum. Faktor-faktor penilaian tingkat kesehatan bank terdiri dari: Profil risiko (risk profile), Good Corporate Governance (GCG), rentabilitas/pendapatan (earnings) dan permodalan (capital) yang disebut dengan metode RGEC.

Peringkat setiap faktor risiko dan komposit ditetapkan berdasarkan kerangka analisis yang komprehensif dan terstruktur terhadap peringkat setiap faktor, dengan memperhatikan materialitas masing-masing faktor, serta mempertimbangkan kemampuan bank dalam menghadapi perubahan kondisi eksternal yang signifikan.

Penilaian Risk-Based Bank Rating (RBBR), yaitu:

1. Penilaian Faktor Profil Risiko

Penilaian terhadap faktor profil risiko merupakan penilaian terhadap risiko inheren dan kualitas penerapan manajemen risiko dalam operasional bank yang dilakukan terhadap 8 (delapan) risiko, yaitu:

a. Risiko kredit;

Risiko kredit adalah risiko akibat kegagalan debitur dan/atau pihak lain dalam memenuhi kewajiban kepada Bank. Risiko kredit pada umumnya terdapat pada seluruh aktivitas Bank yang 
kinerjanya bergantung pada kinerja pihak lawan (counterparty), Penerbit (issuer) atau kinerja debitur (borrower).

b. Risiko pasar;

Risiko Pasar adalah Risiko pada posisi neraca dan rekening administratif termasuk transaksi derivatif, akibat perubahan dari kondisi pasar, termasuk Risiko perubahan harga option Risiko likuiditas;

c. Risiko Likuiditas

Risiko likuiditas umumnya terjadi setelah terjadinya risiko yang lain, misalnya akibat adanya pembiayaan macet, akibat reputasi bank yang memburuk sehingga bank tidak memiliki cukup dana untuk memenuhi kewajibannya.

d. Risiko operasional;

Risiko Operasional adalah Risiko akibat ketidakcukupan dan/atau tidak berfungsinya proses internal, kesalahan manusia, kegagalan sistem, dan/atau adanya kejadian eksternal yang mempengaruhi operasional Bank

e. Risiko hukum;

Risiko Hukum adalah Risiko yang timbul akibat tuntutan hukum dan/atau kelemahan aspek yuridis

f. Risiko strategis;

Risiko Stratejik adalah Risiko akibat ketidaktepatan Bank dalam mengambil keputusan dan/atau pelaksanaan suatu keputusan stratejik serta kegagalan dalam mengantisipasi perubahan lingkungan bisnis.

g. Risiko kepatuhan;

Risiko Kepatuhan adalah Risiko yang timbul akibat Bank tidak mematuhi dan/atau tidak melaksanakan peraturan perundang-undangan dan ketentuan yang berlaku

h. Risiko reputasi.

Risiko Reputasi adalah Risiko akibat menurunnya tingkat kepercayaan stakeholder yang bersumber dari persepsi negatif terhadap Bank.

2. Penilaian Tata Kelola Risiko (GCG)
Bank wajib melaksanakan prinsip-prinsip good corporate governance dalam setiap kegiatan usahanya pada seluruh tingkatan atau jenjang organisasi termasuk pada saat penyusunan visi, misi, rencana strategis, pelaksanaan kebijakan dan langkah-langkah pengawasan internal.

Penilaian terhadap faktor tata kelola risiko atau GCG merupakan penilaian terhadap manajemen bank atas pelaksanaan prinsipprinsip GCG. Prinsip-prinsip GCG dan fokus penilaian terhadap pelaksanaan prinsip-prinsip GCG mengacu pada ketentuan Bank Indonesia mengenai good corporate governance bagi bank umum dengan memperhatikan karekteristik dan kompleksitas usaha bank. Pengukuran rating GCG dilakukan terhadap struktur, proses dan hasil yang diperoleh dari pelaksanaan GCG yang diterjemahkan dalam pengukuran oleh Bank Indonesia (sekarang oleh OJK) untuk memperoleh peringkat atau rating GCG.

3. Penilaian Faktor Rentabilitas

Penilaian faktor Rentabilitas meliputi evaluasi terhadap kinerja Rentabilitas, sumbersumber Rentabilitas, kesinambungan (sustainability) Rentabilitas, dan manajemen Rentabilitas

4. Penilaian Faktor Pemodalan

Penilaian atas faktor Permodalan meliputi evaluasi terhadap kecukupan Permodalan dan kecukupan pengelolaan Permodalan.

\subsection{Menetapkan Bobot Peringkat Komposit}

Menetapkan peringkat komposit penilaian tingkat kesehatan bank dari tahun 2013 hingga tahun 2017. Nilai komposit untuk rasio keuangan masing-masing komponen yang menempati peringkat komposit akan bernilai sebagai berikut:

1. Peringkat $1=$ setiap kali ceklist dikalikan dengan 5

2. Peringkat $2=$ setiap kali ceklist dikalikan dengan 4

3. Peringkat $3=$ setiap kali ceklist dikalikan dengan 3

4. Peringkat $4=$ setiap kali ceklist dikalikan dengan 2 
5. Peringkat $5=$ setiap kali ceklist dikalikan dengan 1

Nilai komposit yang telah diperoleh dari mengalikan tiap ceklist kemudian ditentukan bobotnya dengan mempresentasekan. Adapun bobot/presentase untuk menentukan peringkat komposit keseluruhan komponen sebagai berikut:

Tabel 2. Bobot Penetapan Peringkat Komposit

\begin{tabular}{lcc}
\hline Bobot \% & $\begin{array}{c}\text { Peringkat } \\
\text { Komposit }\end{array}$ & Ket. \\
\hline $86-100$ & PK 1 & $\begin{array}{c}\text { Sangat } \\
\text { Sehat }\end{array}$ \\
\hline $71-85$ & PK 2 & Sehat \\
\hline $61-70$ & PK 3 & $\begin{array}{c}\text { Cukup } \\
\text { Sehat }\end{array}$ \\
\hline $41-60$ & PK 4 & $\begin{array}{c}\text { Kurang } \\
\text { Sehat }\end{array}$ \\
\hline$<40$ & PK 5 & $\begin{array}{c}\text { Tidak } \\
\text { Sehat }\end{array}$ \\
\hline
\end{tabular}

Sumber: Refmasari dan Setiawan. (2014)

Peringkat Komposit $=$

$\frac{\text { Jumlah Nilai Komposit }}{\text { Total Nilai Komposit Keseluruhan }} \times 100 \%$

Sumber: Refmasari dan Setiawan. (2014)

\subsection{Definisi Operasional}

Variabel dalam penelitian ini adalah penilaian tingkat kesehatan bank di PT Bank Muamalat Indonesia, Tbk pada tahun 2013 2017. Secara lebih rinci, operasionalisasi variabel penelitian adalah sebagai berikut :

a. Risk Profile (Profil Risiko) yang terdiri dari indikator:

1. Risiko Kredit

Non Performing Financing (NPF) untuk mengetahui risiko kredit dihitung menggunakan rasio NPF. Rasio keuangan ini menerangkan bahwa NPF diperoleh dari pembiayaan bermasalah yaitu pembiayaan kepada pihak ketiga bukan bank yang tergolong kurang lancar, diragukan dan macet dibagi dengan total pembiayaan kepada pihak ketiga bukan bank. Rumus NPF yaitu:

$$
\mathrm{NPF}=\frac{\text { Pembiayaan Bermasalah }}{\text { Total Pembiayaan }} \times 100 \%
$$

2. Risiko Likuiditas

Risiko likuiditas adalah risiko akibat ketidakmampuan bank untuk memenuhi kewajiban yang jatuh tempo dari sumber pendanaan arus kas dan/atau dari asset likuid berkualitas tinggi yang dapat diagunkan, tanpa menganggu aktivitas dari kondisi keuangan bank. Risiko likuiditas disebut juga risiko likuiditas pendanaan (funding liquidty risk) dan risiko likuiditas pasar (market liquidty risk). Rasio ini dirumuskan dengan menghitung Financing to Deposit Ratio (FDR) yaitu sebagai berikut :

$$
\mathrm{FDR}=\frac{\text { Total Pembiayaan }}{\text { Dana Pihak Ketiga }} \times 100 \%
$$

\section{b. Good Corporate Governance (GCG)}

Indikator penilaian pada Good Corporate Governance (GCG) yaitu menggunakan bobot penilaian berdasarkan nilai komposit dari ketetapan Bank Indonesia menurut PBI No.13/ 1/ PBI/ 2011 tentang penilaian tingkat kesehatan bank umum, yaitu self assessment bank. Penerapan Good Corporate Governance pada bank dimaksudkan untuk meningkatkan kinerja bank.

\section{c. Rentabilitas (Earning)}

Penilaian faktor rentabilitas bank dapat menggunakan indikator diantaranya sebagai berikut:

\section{ROA (Return on Asset)}

Return on Asset (ROA) merupakan rasio untuk mengukur kemampuan bank menghasilkan laba dengan menggunakan asetnya (Taswan, 2010). Perhitungan ROA adalah sebagai berikut:

$$
\mathrm{ROA}=\frac{\text { Laba Sebelum Pajak }}{\text { Rata-rata Total Aset }} \times 100 \%
$$


2. (ROE) Return On Equity

Return On Equity (ROE) merupakan rasio untuk mengukur kemampuan bank dalam memperoleh keuntungan bersih dikaitkan dengan pembayaran deviden. Rasio ini dirumuskan dengan:

$$
\begin{aligned}
& \text { ROE }=\frac{\text { Laba Setelah Pajak }}{\text { Modal Sendiri }} \times 100 \% \\
& \text { 3. Beban Operasional terhadap } \\
& \text { Pendapatan Operasional (BOPO) }
\end{aligned}
$$

Beban operasional terhadap pendapatan operasional adalah rasio yang digunakan untuk mengukur tingkat efisien dan kemampuan bank dalam melakukan kegiatan operasinya. Rasio ini dirumuskan dengan:

$$
\mathrm{BOPO}=\frac{\text { Beban Operasional }}{\text { Pendapatan Operasional }} \times 100 \%
$$

\section{d. Permodalan (Capital)}

\section{Capital Adequacy Ratio (CAR)} merupakan rasio yang digunakan untuk menghitung kesehatan permodalan bank. CAR (Capital Adequacy Ratio) adalah rasio yang memperlihatkan seberapa besar jumlah seluruh aktiva bank yang mengandung risiko (kredit, penyertaan, surat berharga, tagihan pada bank lain) ikut dibiayai dari modal sendiri disamping memperoleh dana-dana dari sumber-sumber di luar bank (Dendawijaya, 2003 dalam Dharmapermata 2015:41). Rasio ini dapat dirumuskan sebagai berikut (Surat Edaran Bank Indonesia No.13/24/DPNP tanggal 25 Oktober 2011) :

$$
\mathrm{CAR}=\frac{\text { Modal Bank }}{\text { Total Aktiva Tertimbang Menurut Risiko }} \times 100 \%
$$

\subsection{Kerangka Pemikiran}

Hasil perhitungan rasio dari beberapa indikator tersebut kemudian ditentukan peringkat kompositnya sehingga akan diketahui tingkat kesehatan Bank Muamalat Indonesia, Tbk. Berikut ini merupakan gambar skema kerangka pemikiran penelitian, sebagai berikut:

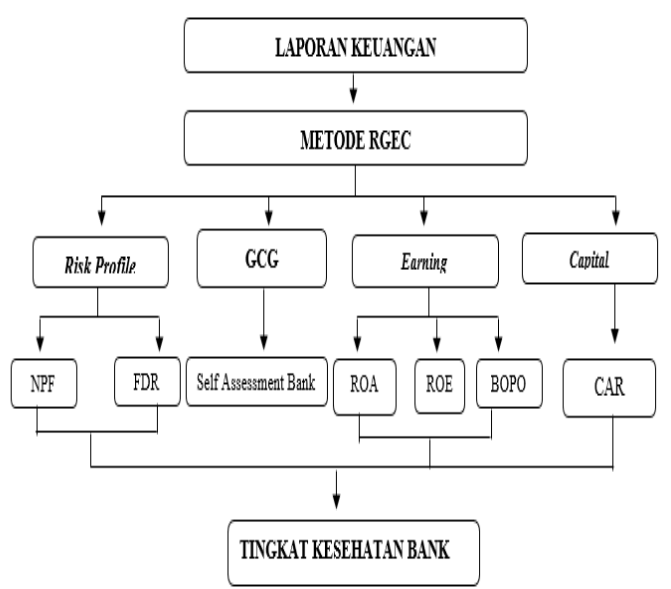

\section{Gambar 1. Kerangka Pemikiran}

\section{METODE PENELITIAN}

Penelitian ini menggunakan data deskriptif kuantitatif. Variabel dalam penelitian ini adalah variabel mandiri, yaitu penilaian tingkat kesehatan bank yang terdiri dari Profil Risiko (Risk Profile), Good Corporate Governance, Rentabilitas (Earning) dan Permodalan (Capital). Objek dari penelitian ini adalah laporan keuangan pada PT Bank Muamalat Indonesia, Tbk. Penelitian ini menggunakan teknik pengambilan data sekunder yaitu sumber data penelitian yang dilakukan secara tidak langsung. Penelitian ini menggunakan teknik analisis perbandingan yang merupakan bagian dari analisis horizontal (dinamis) yaitu analisis yang dilakukan dengan membandingkan laporan keuangan dari beberapa periode. Untuk mengetahui bank dalam kategori sehat ataupun tidak maka terdapat penetapan peringkat matriks pada masing-masing faktor RGEC yaitu:

1. Risiko Kredit

Matriks kriteria penetapan peringkat risiko kredit yaitu:

Tabel 3. Matriks Kriteria Penetapan Peringkat Profil Risiko (NPF)

\begin{tabular}{ccc}
\hline Peringkat & Keterangan & Kriteria \\
\hline 1 & $\begin{array}{c}\text { Sangat } \\
\text { Sehat }\end{array}$ & NPF $<2 \%$ \\
\hline 2 & Sehat & $\begin{array}{c}2 \% \leq \mathrm{NPF}< \\
5 \%\end{array}$ \\
\hline
\end{tabular}




\begin{tabular}{ccc}
\hline 3 & Cukup Sehat & $\begin{array}{c}5 \% \leq \mathrm{NPF}< \\
8 \%\end{array}$ \\
\hline 4 & $\begin{array}{c}\text { Kurang } \\
\text { Sehat }\end{array}$ & $\begin{array}{c}8 \% \leq \mathrm{NPF}< \\
12 \%\end{array}$ \\
\hline 5 & Tidak Sehat & $\mathrm{NPF} \geq 12 \%$ \\
\hline
\end{tabular}

Sumber : Surat Edaran Bank Indonesia No. 13/24/DPNP Tahun 2011

\section{Risiko Likuiditas}

Matriks kriteria penetapan peringkat risiko likuiditas yaitu:

Tabel 4. Matriks Kriteria Penetapan Peringkat Profil Risiko (FDR)

\begin{tabular}{|c|c|c|}
\hline Peringkat & Keterangan & Kriteria \\
\hline 1 & Sangat sehat & FDR $<75 \%$ \\
\hline 2 & Sehat & $75 \% \leq \mathrm{FDR}<85 \%$ \\
\hline 3 & Cukup sehat & $85 \% \leq \mathrm{FDR}<100 \%$ \\
\hline 4 & Kurang sehat & $100 \% \leq \mathrm{FDR}<120 \%$ \\
\hline 5 & Tidak sehat & $\mathrm{FDR} \geq 120 \%$ \\
\hline
\end{tabular}

Sumber : Surat Edaran Bank Indonesia No. 6/23/DPNP Tahun 2004

\section{Good Corporate Governance (GCG)}

Penilaian pada faktor GCG berdasarkan PBI No 13/1/PBI/2011 Tentang Penilaian Tingkat Kesehatan Bank yaitu menggunakan penilaian pelaksanaan tugas dan tanggung jawab dewan komisaris, pelaksanaan tugas dan tanggung jawab direksi, kelengkapan dan pelaksanaan tugas komite, penanganan benturan kepentingan, penerapan fungsi kepatuhan bank, penerapan fungsi audit internal, penerapan fungsi audit ekstern, fungsi manajemen risiko termasuk sistem pengendalian internal, penyediaan dana kepada pihak terkait dan debitur besar, transparansi kondisi keuangan dan non keuangan, laporan pelaksanaan GCG dan pelaporan internal, dan rencana strategis bank.

\section{Rentabilitas (Earning) \\ a. ROA (Return On Asset)}

Matriks kriteria penetapan peringkat Return On Asset yaitu:
Tabel 5. Matriks Kriteria Penetapan Peringkat Return on Asset (ROA)

\begin{tabular}{ccc}
\hline Peringkat & Keterangan & Kriteria \\
\hline 1 & $\begin{array}{c}\text { Sangat } \\
\text { sehat }\end{array}$ & ROA $>1,5 \%$ \\
\hline 2 & Sehat & $1,25 \%<$ ROA $\leq$ \\
& & $1,5 \%$ \\
\hline 3 & Cukup & $0,5 \%<$ ROA $\leq$ \\
& sehat & $1,25 \%$ \\
\hline 4 & Kurang & $0 \%<$ ROA $\leq 0,5 \%$ \\
& sehat & \\
\hline 5 & Tidak sehat & ROA $\leq 0 \%$
\end{tabular}

Sumber : Kodifikasi Penilaian Tingkat Kesehatan Bank Tahun 2012

b. Return On Equity (ROE)

Matriks kriteria penetapan peringkat Return On Equity yaitu:

Tabel 6. Matriks Kriteria Penetapan Peringkat Return On Equity (ROE)

\begin{tabular}{|c|c|c|}
\hline Peringkat & Keterangan & Kriteria \\
\hline 1 & Sangat sehat & $\begin{array}{c}\text { Perolehan laba } \\
\text { sangat sehat (rasio } \\
\text { diatas } 20 \% \text { ) }\end{array}$ \\
\hline 2 & Sehat & $\begin{array}{l}\text { Perolehan laba tingi } \\
\text { (rasio ROE berkisar } \\
\text { antara } 12,51 \% \\
\text { sampai dengan } 20 \% \text { ) }\end{array}$ \\
\hline 3 & Cukup sehat & $\begin{array}{c}\text { Perolehan laba cukup } \\
\text { tinggi (rasio ROE } \\
\text { berkisar antara } \\
5,01 \% \text { sampai } \\
\text { dengan } 12,5 \% \text { ) }\end{array}$ \\
\hline 4 & Kurang sehat & $\begin{array}{c}\text { Perolehan laba } \\
\text { rendah atau } \\
\text { cenderung } \\
\text { mengalami kerugian } \\
\text { (ROE mengarah } \\
\text { negatif rasio berkisar } \\
\text { antara } 0 \% \text { sampai } \\
\text { dengan 5\%) }\end{array}$ \\
\hline 5 & Tidak sehat & $\begin{array}{l}\text { Bank mengalami } \\
\text { kerugian yang besar } \\
\text { (ROE negatif, rasio } \\
\text { di bawah } 0 \% \text { ) }\end{array}$ \\
\hline
\end{tabular}

Sumber : Surat Edaran Bank Indonesia No. 13/24/DPNP tahun 2011 
c. Beban Operasional terhadap Pendapatan Operasional (BOPO)

Matriks kriteria penetapan peringkat Beban Operasional terhadap Pendapatan Operasional yaitu:

Tabel 7. Matriks Kriteria Penetapan Peringkat Beban Operasional terhadap Pendapatan Operasional (BOPO)

\begin{tabular}{|c|c|c|}
\hline Peringkat & Ket. & Kriteria \\
\hline 1 & $\begin{array}{c}\text { Sangat } \\
\text { sehat }\end{array}$ & $\begin{array}{c}\text { Tingkat efisiensi } \\
\text { sangat baik (rasio } \\
\text { BOPO kurang dari } \\
83 \% \text { ) }\end{array}$ \\
\hline 2 & Sehat & $\begin{array}{c}\text { Tingkat efisiensi } \\
\text { baik (rasio BOPO } \\
\text { berkisar antara } 83 \% \\
\text { sampai dengan } 85 \% \text { ) }\end{array}$ \\
\hline 3 & $\begin{array}{c}\text { Cukup } \\
\text { sehat }\end{array}$ & $\begin{array}{l}\text { Tingkat efisiensi } \\
\text { cukup baik (rasio } \\
\text { BOPO berkisar } \\
\text { antara } 85 \% \text { sampai } \\
\text { dengan } 87 \% \text { ) }\end{array}$ \\
\hline 4 & $\begin{array}{c}\text { Kurang } \\
\text { sehat }\end{array}$ & $\begin{array}{l}\text { Tingkat efisiensi } \\
\text { cukup baik (rasio } \\
\text { BOPO berkisar } \\
\text { antara } 87 \% \text { sampai } \\
\text { dengan } 89 \% \text { ) }\end{array}$ \\
\hline 5 & $\begin{array}{l}\text { Tidak } \\
\text { sehat }\end{array}$ & $\begin{array}{c}\text { Tingkat efisiensi } \\
\text { sangat buruk (rasio } \\
\text { diatas } 89 \% \text { ) }\end{array}$ \\
\hline
\end{tabular}

Sumber : Surat Edaran Bank Indonesia No. 13/24/DPNP tahun 2011

e. Permodalan (Capital)

Matriks kriteria penetapan peringkat permodalan yaitu:

Tabel 8. Matriks Kriteria Penetapan Peringkat Capital Adequacy Ratio (CAR)

\begin{tabular}{ccc}
\hline Peringkat & Keterangan & Kriteria \\
\hline 1 & $\begin{array}{c}\text { Sangat } \\
\text { sehat }\end{array}$ & CAR $>12 \%$ \\
\hline 2 & Sehat & $9 \% \leq \mathrm{CAR}<$ \\
\hline
\end{tabular}

\begin{tabular}{ccc}
\hline & & $12 \%$ \\
\hline 3 & Cukup & $8 \% \leq \mathrm{CAR}<$ \\
& sehat & $9 \%$ \\
\hline 4 & Kurang & $6 \% \leq \mathrm{CAR}<$ \\
& sehat & $8 \%$ \\
\hline 5 & Tidak sehat & CAR $\leq 6 \%$ \\
\hline
\end{tabular}

Sumber : Surat Edaran Bank Indonesia No. 13/24/DPNP tahun 2011

\section{HASIL DAN PEMBAHASAN}

Hasil penilaian kesehatan PT Bank Muamalat Indonesia, Tbk berdasarkan metode RGEC (Risk Profile, Good Corporate Governance, Earning, dan Capital) selama 5 (lima) tahun pada tahun 2013-2017 dapat disajikan dalam tabel sebagai berikut:

Tabel 9. Penilaian Tingkat Kesehatan PT Bank Muamalat Indonesia, Tbk berdasarkan Metode RGEC pada tahun 2013-2017

\begin{tabular}{|c|c|c|c|c|c|c|c|c|}
\hline \multirow[t]{2}{*}{ Tahun } & \multirow[t]{2}{*}{ Komponen } & \multirow[t]{2}{*}{ Rasio } & \multirow[t]{2}{*}{ Nilai } & \multicolumn{3}{|c|}{ Peringkat } & \multirow[t]{2}{*}{ Kriteria } & \multirow[t]{2}{*}{ Komposit } \\
\hline & & & & 1 & $\begin{array}{lll}2 & 3 & 4\end{array}$ & 5 & & \\
\hline \multirow[t]{8}{*}{2013} & Risk Profile & NPF & 1.35 & $\sqrt{1}$ & & & Sangat Sehat & Sehat \\
\hline & & FDR & 99.99 & & 1 & & Cukup Sehat & \\
\hline & $G C G$ & & 1.15 & $\sqrt{1}$ & & & Sangat Sehat & \\
\hline & Earning & ROA & 1.31 & & $\sqrt{1}$ & & Sehat & \\
\hline & & ROE & 11.77 & & 1 & & Cukup Sehat & \\
\hline & & BOPO & 85.21 & & 1 & & Cukup Sehat & \\
\hline & Capital & CAR & 17.38 & 1 & & & Sangat Sehat & \\
\hline & Nilai Kompos & & & 15 & $\begin{array}{lll}4 & 9 & -\end{array}$ & $\cdot$ & $(28: 35) \times 100 \%=$ & $80 \%$ \\
\hline \multirow[t]{2}{*}{ Tahun } & Komponen & Rasio & Nilai & & Peringkat & & Kriteria & Komposit \\
\hline & & & & 1 & 234 & 5 & & \\
\hline \multirow[t]{8}{*}{2014} & Risk Profile & NPF & 6.51 & & $\sqrt{ }$ & & Cukup Sehat & Kurang \\
\hline & & FDR & 84.14 & & $\sqrt{ }$ & & Sehat & \\
\hline & $G C G$ & & - & & $\sqrt{ }$ & & Cukup Sehat & \\
\hline & Earning & $\mathrm{ROA}$ & 0.17 & & $\sqrt{ }$ & & Kurang Sehat & \\
\hline & & $\mathrm{ROE}$ & 1.71 & & $\sqrt{ }$ & & Kurang Sehat & \\
\hline & & BOPO & 97.33 & & & $\sqrt{ }$ & Tidak Sehat & \\
\hline & Capital & CAR & 14.22 & 1 & & & Sangat Sehat & \\
\hline & Nilai Komp & & & 5 & 464 & 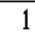 & $(20: 35) \times 100 \%$ & $=57.14 \%$ \\
\hline
\end{tabular}




\begin{tabular}{|c|c|c|c|c|c|c|}
\hline \multirow{2}{*}{\multicolumn{2}{|c|}{ Risk Profile }} & NPF & 7.11 & $\sqrt{1}$ & Cukup Sechat & \multirow{7}{*}{$\begin{array}{c}\text { Kurang } \\
\text { Sehat }\end{array}$} \\
\hline & & $\overline{\mathrm{FDR}}$ & 90.37 & $\sqrt{1}$ & Cukup Sehat & \\
\hline & $\overline{G C G}$ & & . & $\sqrt{1}$ & Cukno Sethat & \\
\hline & \multirow[t]{3}{*}{ Earning } & $\mathrm{ROA}$ & 0.18 & $\sqrt{1}$ & Kurangng Sehat & \\
\hline & & $\overline{\mathrm{ROE}}$ & 2.27 & $\sqrt{1}$ & Kurang Sehat & \\
\hline & & $\overline{\mathrm{BOPO}}$ & 96.83 & $\sqrt{1}$ & Tidalk Sehat & \\
\hline & Capital & CAR & 12.36 & & Sangat Sehat & \\
\hline
\end{tabular}

\begin{tabular}{lllllll}
\hline Nilai Komposit & 5 & -9 & 4 & 1 & $(19: 35) \times 100 \%=54.28 \%$
\end{tabular}

\begin{tabular}{|c|c|c|c|c|c|c|c|}
\hline \multirow[t]{2}{*}{ Tahun } & \multirow[t]{2}{*}{ Komponen } & \multirow[t]{2}{*}{ Rasio } & \multirow[t]{2}{*}{ Nilai } & \multicolumn{2}{|c|}{ Peringkat } & \multirow[t]{2}{*}{ Kriteria } & \multirow[t]{2}{*}{ Komposit } \\
\hline & & & & 1 & 2345 & & \\
\hline \multirow[t]{8}{*}{2016} & RiskProfile & NPF & 3.81 & & $\sqrt{ }$ & Sehat & Kurang \\
\hline & & \begin{tabular}{l|l}
$\mathrm{FDR}$ \\
\end{tabular} & 95.44 & & $\sqrt{1}$ & Cukup Sehat & Sehat \\
\hline & $\overline{G C G}$ & & - & & V & Sehat & \\
\hline & Earming & ROA & 0.21 & & T & Kurang Sehat & \\
\hline & & $\begin{array}{l}\mathrm{ROE} \\
\end{array}$ & 2.42 & & $\sqrt{1}$ & Kurang Sehat & \\
\hline & & $\overline{\mathrm{BOPO}}$ & 98.35 & & $\sqrt{ }$ & Tidal Sehat & \\
\hline & $\begin{array}{l}\text { Capital } \\
\end{array}$ & CAR & 12.74 & T & & Sangat Sehat & \\
\hline & $\begin{array}{l}\text { Nilai Kompo } \\
\text {. }\end{array}$ & & & 5 & 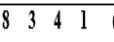 & $(21: 35) \times 100 \%=$ & $60 \%$ \\
\hline \multirow[t]{7}{*}{2017} & Risk Profile & NPF & 4.32 & & $\sqrt{ }$ & Sehat & Kurang \\
\hline & & FDR & 84.80 & & $\sqrt{ }$ & Sehat & Sehat \\
\hline & GCG & & - & & $\sqrt{1}$ & Cukup Sehat & \\
\hline & Earning & ROA & 0.10 & & $\sqrt{1}$ & Kurang sehat & \\
\hline & & ROE & 0.52 & & $\sqrt{1}$ & Kurang Sehat & \\
\hline & & BOPO & 99.45 & & 1 & Tidak Sehat & \\
\hline & Capital & CAR & 13.62 & & & Sangat Sehat & \\
\hline
\end{tabular}

Sumber: Data Sekunder yang diolah (2018)

Penilaian tingkat kesehatan bank pada PT Bank Muamalat Indonesia, Tbk dengan menggunakan metode RGEC yaitu dengan melihat aspek Risk Profile, Good Corporate Governance, Earning dan Capital selama 5 (lima) tahun periode 2013 - 2017 berada pada peringkat komposit 4 (PK-4). Dengan rincian bahwa pada tahun 2013-2017 peringkat komposit Bank Muamalat adalah 80\%, $57.14 \%, 54,28 \%, 60 \%$ dan $60 \%$. Rata-rata nilai komposit yang diperoleh Bank Muamalat selama periode tahun tersebut berada pada peringkat komposit 4 (PK-4).

Berdasarkan Peraturan Bank Indonesia No. 13/01/PBI/2011 bank yang memperoleh peringkat komposit 4 mencerminkan bahwa kondisi bank yang secara umum kurang sehat.

\section{KESIMPULAN DAN SARAN}

\subsection{Kesimpulan}

Berdasarkan rumusan masalah, hasil penelitian dan pembahasan yang telah dilakukan, dapat disimpulkan bahwa tingkat kesehatan bank pada PT Bank Muamalat Indonesia, Tbk dengan menggunakan metode RGEC pada tahun 2013 sampai dengan 2017 adalah sebagai berikut:

1. Hasil penilaian tingkat kesehatan bank dilihat dari Aspek RGEC (Risk Profile, Good Corporate Governance, Earning, dan Capital) selama tahun 2013-2017 menempati Peringkat Komposit 4 (PK-4). Sehingga mencerminkan kondisi bank yang secara umum Kurang Sehat dinilai kurang mampu menghadapi pengaruh negatif yang signifikan dari perubahan kondisi bisnis dan faktor eksternal lainnya, tercermin dari faktor penilaian, antara lain rentabilitas yang secara umum kurang baik.

2. a. Hasil penilaian Profil Risiko (Risk Profile) Bank Muamalat dengan menggunakan 2 indikator yaitu faktor risiko kredit dengan menggunakan rasio NPF dan risiko likuiditas dengan menggunakan rasio FDR selama tahun 2013-2017. Pada tahun 2013 nilai rasio NPF dalam kondisi Sangat Sehat dan dipertengahan tahun 2014 dan 2015 mengalami penurunan menjadi Cukup Sehat, posisi terakhir tahun 2016 dan 2017 menjadi Sehat. Pada penilaian rasio FDR tahun 2013 dalam kondisi Cukup Sehat. Pada tahun 2014 meningkat dalam kondisi Sehat. Pada tahun 2015 dan 2016 berturut-turut dalam kondisi Cukup 
Sehat dan posisi terakhir pada tahun 2017 dalam kondisi Sehat.

b. Hasil penilaian Good Corporate Governance (GCG) pada PT Bank Muamalat Indonesia, Tbk pada tahun 2013 memperoleh peringkat 1 dengan predikat Sangat Baik. Pada tahun 2014 dan 2015 berturut-turut memperoleh peringkat 3 dengan predikat Cukup Baik. Pada tahun 2016 memperoleh peringkat 2 dengan predikat Baik dan posisi terakhir pada tahun 2017 memperoleh peringkat 3 Cukup Baik. Hal ini menunjukkan bahwa pelaksanaan prinsip-prinsip GCG selama lima tahun tersebut berjalan dengan cukup baik.

c. Hasil penilaian Rentabilitas (Earning) pada Bank Muamalat dengan menggunakan 3 rasio yaitu ROA, ROE dan BOPO selama tahun 2013-2017. Pada tahun 2013 nilai rasio ROA dalam kondisi Sehat dan pada tahun 2014 sampaidengan 2017 berturut-turut dalam kondisi Kurang Sehat. Pada penilaian rasio ROE tahun 2013 dalam kondisi Cukup Sehat dan pada tahun 2014 sampai dengan 2017 berturut- turut dalam kondisi Kurang Sehat. Pada penilaian rasio BOPO tahun 2013 dalam kondisi Cukup Sehat, namun pada tahun 2014 sampai dengan 2017 berturut-turut dalam kondisi Tidak Sehat. Hal ini menunjukkan bahwa Bank Muamalat kurang mampu dalam mengelola aset untuk meningkatkan pendapatan dan menekan biaya.

d. Hasil penilaian permodalan (Capital) pada Bank Muamalat selama tahun 2013-2017 berada dalam kondisi Sangat Sehat. Hal ini menunjukkan bahwa selama periode tersebut Bank Muamalat telah mampu mengelola permodalan perusahaan dengan sangat baik.

\subsection{Saran}

2. Bagi pihak bank

Bank Muamalat harus tetap menjaga tingkat kesehatan bank pada tahun-tahun berikutnya agar dapat lebih meningkatkan kepercayaan masyarakat, nasabah dan stakeholder terhadap Bank Muamalat. Hendaknya Bank Muamalat dapat menaikan peringkat untuk ROA, ROE dan BOPO dari peringkat 4 dan 5 yaitu kurang sehat dan tidak sehat menjadi peringkat 1 sangat sehat agar dapat mempertahankan kinerja perusahaan dengan meningkatkan perolehan laba. Hendaknya bank dapat meningkatkan laba yang besar untuk menarik investor ke Bank Muamalat Indonesia karena memiliki tingkat pengembalian yang semakin tinggi. Hendaknya, Bank Muamalat pun dapat menurunkan nilai BOPO sehingga dengan penurunan rasio BOPO bank mampu meningkatkan pendapatannya dan di saat bersamaan mampu menekan biaya operasionalnya.

2. Bagi Penelitian Selanjutnya

Bagi penelitian selanjutnya diharapkan dapat menambah periode penelitian dan menambah rasio keuangan dan rasio non keuangan lainnya agar diperoleh perhitungan dan analisis yang lebih menyeluruh dan akurat dalam perhitungan kinerja dan kesehatan bank dengan metode RGEC.

\section{DAFTAR PUSTAKA}

Anisah Putri. 2018. Analisis Penilaian Tingkat Kesehatan Bank dengan Menggunakan Metode RGEC (Risk Profile, Good Corporate Governance, Earning, dan Capital) pada PT Bank Mayapada Internasional, Tbk Periode 2012-2016. Skripsi.

Bank Indonesia. 2011. Peraturan Bank Indonesia Nomor 13/1/PBI/2011 Tentang Penilaian Tingkat Kesehatan Bank Umum. 
Bank Muamalat. 2017, 2016, 2015, 2014, 2013. Laporan Tahunan Bank Muamalat Indonesia. Jakarta: Bank Muamalat Indonesia.

Emilia. 2017. "Analisis Tingkat Kesehatan Bank dengan Metode RGEC (Risk Profile, Good Corporate Governance, Earning and Capital) pada PT BNI Syariah”. Jurnal

Ikatan Bankir Indonesia. 2015. Manajemen Risiko 3. PT Gramedia Pustaka Utama: Jakarta Pusat.

Ikatan Bankir Indonesia. 2016. Manajemen Kesehatan Bank Berbasis Risiko. PT Gramedia Pustaka Utama: Jakarta Pusat.

Sandhy Dharmapermata S. 2015. Analisis Tingkat Kesehatan Bank dengan Menggunakan Metode Risk-Based Bank Rating (RBRR). Skripsi

Surat Edaran Bank Indonesia. 2011. No. 13/24/DPNP Perihal Penilaian Tingkat Kesehatan Bank Umum. Jakarta: Bank Indonesia.

Thertina, Martha Ruth. 2016. Lima Bank Syariah Pikul Beban Berat Pembiayaan Bermasalah.https://katadata.co.id/berita/2 016/09/30/lima-bank-syariah-pikulbeban-berat-pembiayaan-macet.

Zakaria, Zeze.2018. Jurnal Economicus, Vol. 9 No. 2.Analisis likuiditas, rentabilitas dan solvabilitas untuk menilai kinerja keuangan PT Bakrie Sumatera Plantation, Tbk.

http://ejournal.dewantara.ac.id/index.php/ economicus/article/view/58/34. 